\author{
Sabire Arık \\ http://orcid.org/0000-0003-3662-9866 \\ Ankara University, Ankara \\ sarik@ankara.edu.tr \\ DOI: $10.35765 /$ pk.2020.3104.06
}

\title{
The First Turkish Navy Admiral: Chaka Bey
}

\section{AB S TRAC T}

Turks paid special attention to the organization of ground troops due to their geographical location in Central Asia which is why they built the strongest land army in the world. Their first naval endeavor emerged after the conquest of Anatolia. This was because of Anatolia's geographical position, being an Asian peninsula extending towards the west and situated between the continents of Europe and Asia, and also a conjunction of land and sea routes between the continents. With the start of the Turkish conquest of Anatolia after the victorious Battle of Malazgirt in 1071, the strategy of Turkish domination changed. The new rulers of the area surrounded by sea from three sides realized that the way to protect their territory was the domination of the seas. During this period, mass migration took place from Turkey to the region of western Anatolia, and on the other hand, Chaka Bey (Çaka Bey) managed to dominate Smyrna (Izmir) after the change on the throne of the Byzantine Empire in 1081. He established a Turkish Seaside Principality (Türk Sahil Beyliği or $\dot{I}_{z m i r}$ Türk Beyliği). Although his life was short, the first coastal Turkish state is significant from the point of view of Turkish history, meaning that the history of the Turkish navy starts in 1081, which is the date of the first fleet built by Chaka Bey.

KEYWORD S : Turkey, Anatolia, Çaka Bey, Turkish maritime history, history of the Turkish Navy

\section{STRESZCZENIE}

\section{Pierwszy admirał tureckiej marynarki wojennej: Czaka Bej}

Turcy zwracali szczególną uwagę na naziemną organizację wojskową ze względu na położenie geograficzne Azji Środkowej i na tym terenie utworzyli najsilniejsze armie lądowe na świecie. Założona przez nich pierwsza organizacja należąca do sektora morskiego powstała po podboju Anatolii - półwyspu rozciągającego się na zachód i położonego między Europą i Azją, a także połączeniem szlaków morskich i lądowych między kontynentami. Wraz 
z rozpoczęciem turkizacji ziem anatolijskich po zwycięstwie Manzikerta w 1071 roku zmieniła się także strategia dominacji Turków, a nowi właściciele tego kraju otoczonego morzami z trzech stron zdali sobie sprawę, że sposobem ochrony ich ziem była dominacja nad morzami. W tym okresie z jednej strony zatłoczone masy tureckie zaczęły przenikać do regionu zachodniej Anatolii, a z drugiej strony Czaka Bej (po turecku Çaka Bey), który zdołał zdobyć Smyrnę (po turecku Izmir) po zmianie tronu w Bizancjum w 1081 roku, założył tu Tureckie Księstwo Nadmorskie (po turecku Türk Sahil Beyliği lub İzmir Türk Beyliği). Chociaż jego życie było krótkie, to pierwsze nadmorskie państwo ma duże znaczenie z punktu widzenia historii tureckiej. Najważniejsze, że historia marynarki wojennej tureckiej zaczyna się od roku 1081, który jest datą powstania pierwszej marynarki wojennej założonej przez Czaka Beja.

SŁOWA KLUCZE: Turcja, Anatolia, Czaka Bej, turecka historia morska, historia marynarki wojennej tureckiej

Whoever rules the waves rules the world. ${ }^{1}$

\section{Introduction}

Turks paid special attention to the organization of ground troops due to the geographical location of Central Asia and so they built the strongest land army in the world there. However, it is not known if they had any relationship with the sea. What we do know is that the Caspian Sea and the Aral Sea in Central Asia, as well as the rivers Siri-Derya (Seyhun) and Amu Derya (Ceyhun) were called "sea rivers." In addition, the presence of maritime terms such as Taluy/Toluy (ocean) and Tegzinç (anaphora) in ancient Turkish also gives rise to the idea that despite their geography, the Turks were not as far from the sea as we used to think they were. (Alkayıs, 2014, p. 3). The Turks' on these inland waters was followed by an encounter with the actual sea when the first Turkish clans migrated from the north of the Black Sea into Europe, such as the Western Huns, Khazars and Pechenegs. Once they conquered Anatolia in the $11^{\text {th }}$ century, the Turks owned a country surrounded by the sea from three sides. ${ }^{2}$

1 It is not known when and where these words were first uttered, but this meaningful and valuable sentence has been very widely used and attributed to the greatest admiral in Turkish history, Hayreddin Barbarossa Pasha.

2 This Turkish conquest spread from Anatolia to the Mediterranean, the Aegean Sea, and the Black Sea. It was the Turks who called these seas "Mediterranean" and "Black Sea;" the source of these names were based on an old Turkish use. When the ancient Turks described geography, it became clear that they established relationships between colors and directions. The colors represent directions; and respectively, blue and green represented east, white $(a k)$ represented 
As it is known, the Seljuks established state organizations in Horosan and Iran just after the Dandanakan war, which was won by Tughril (9951063) and Chaghri (989-1060) Bey in 1040 (Figure 2). However, the constant migration to these regions from Central Asia created a need for Turkish clans to find a new homeland. Faced with this situation, the Seljuk dynasty were forced to turn their attention to the west. The situation of Byzantium during this period was also conducive to the acquisition of Anatolia by the Turks. Due to poor political, social, economic, and military policies that the Byzantine emperors applied, especially in Eastern Anatolia, peoples such as Armenians, Syrians, etc. living in Byzantine areas tended to be more amicable towards the Turks (Turan, 1973, p. 50). As a result, the Byzantines lacked national and ethnic forces to oppose external intervention. As a result of the constant and intense Turkish attacks, war between the Byzantine Empire and the Great State of Seljuks became inevitable. The battle of Malazgirt between Sultan Alp Arslan (10291072) and Romanos Diogenes on Friday, August 26, 1071, ended with the victory of Alp Arslan and thus paved the way to Anatolia for Turkish clans (Zonaras, 2008, p. 169). This victory allowed Eastern Anatolia to become a meeting place for newly arrived Turkish groups. Immediately after this victory, the Turkish conquerors ordered by Alp Arslan began the process of conquest of Anatolia (Alptekin, 1987, p. 209; Demirkent, 2005, p. 4; Koca, 1997, p. 2). The Turks who arrived to Anatolia under Kutalmışoğlu Suleiman Shah reached the shores of the Aegean and Marmara as a result of the conquests of 1075-1085. Suleiman Shah, conquering Nice (Iznik in Turkish) in 1075, founded the Turkish Seljuk State, independent of the Great Seljuks (Figure 1). In 1081, Shah concluded a peace treaty with the Byzantine Emperor Alexios I Komnenos, and thus the existence of the Turkish Seljuk State in Anatolia was officially recognized by Byzantium (Turan, 1973, p. 95).

Ebu'l-Kasim (Apelkhasem) (d. 1092), who assumed the Seljuk rule in Nice after the death of Suleiman Shah, broke this agreement with Byzantium by starting attacks on the Marmara coast and the Istanbul Strait (Bosporus) (1085-1086) (Komnena, 1996, p. 198). Not only did Ebu'l Kasim resist the Byzantines, who still wanted to reclaim the Nice castle, but he also wanted to destroy Constantinople and conquer the coast of the Marmara and the islands. Emperor Alexios I Komnenos wanted to stop Ebu'l-Kasım and force him to make peace, but he failed. Ebu'l-Kasim

west, red (al) referred to south and black (kara) to north. And so, they called the north sea the Black one, and the south one they called the Mediterranean Sea. In those days the boundaries of the Mediterranean were established from the north of the Bosporus and stretched along the Marmara and the Aegean Sea to the Straits of Gibraltar (Boşol, 2014, p. 40). 
captured Kios (Kius-Cios-Prousias) (Gemlik) and began building a fleet here. ${ }^{3}$ However, the Byzantine navy under Manuel Boutoumites arrived at the Kios harbor and burned down Turkish ships and the shipyard being built. Ebu'I-Kasım, caught between two fires from the land and sea, had to withdraw to Nice. This was how the first attempt to create a Seljuk Turkish navy ended (Cahen, 1994, p. 91; Daş, 2009, p. 49).

In these years, Chaka Bey (Çaka Bey), one of the beys designated by Alp Arslan for the conquest of Anatolia, also made a similar effort as Ebu'I-Kasim. Chaka Bey, who understood the importance of the sea in the $11^{\text {th }}$ century, established the first Turkish navy, founded the first Turkish coastal state (Türk Sahil Beyliği or İmir Türk Beyliği) (1081-1097), and even fought the first war on sea. This Turkish admiral, who conquered Smyrna and its surroundings, for the first time started serious movement on the seas, conquered strategically important islands such as Lesbos, Chios, Samos and Rhodes, successfully maintained his presence against Byzantium and even planned to conquer Constantinople. This article discusses this first Turkish admiral and his Turkish coastal principality.

\section{Who was Chaka Bey?}

Chaka Bey was a true pioneer in the history of the Turkish navy in Anatolia (Kurat, 1987, p. 39; İlgürel, 1993, p. 186). Although there are few resources on the subject, Anna Komnena provides us with the most detailed information about the name and activities of Chaka Bey, who is among the most recognizable characters in Turkish history (Komnena, 1996, p. 229). Data about Chaka Bey are also found in the work of another historian of the Byzantine era, Zonoras (Zonoras, 2008, p. 165) and several other sources on that period. In Byzantine sources, the name Chaka is transcribed as

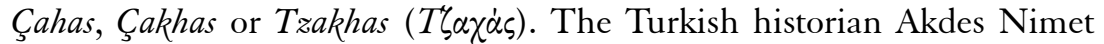
Kurat pointed out that this pronunciation and spelling can actually correspond to the Turkish name Çağa (Kurat, 1966, p. 41). However, another Turkish historian İbrahim Kafesoglu claimed that the original name was Çakan, providing a very convincing explanation (Kafesoğlu, 1984, p. 55).

3 It is not known if Ebu'l-Kasım founded the new shipyard there. Was this shipyard rebuilt or was taken over from the Byzantines? Similarly, who was a qualified master shipbuilder and who were the sailors prepared to use the ships? All these questions are still to be answered. However, taking into account that it was a naval base in the Byzantine period, it can be concluded that there was a shipyard before. Skilled personnel and sailors were probably native Byzantines. 
Nevertheless, the form of Çaka became extremely popular in Turkish literature, and the form Çaka Bey was preferred by adding the adjective Bey.

The Byzantine historian Zonoras presented Chaka Bey as someone of a "noble class, a hero and a great Turk", prompting researchers to predict his social background (Zonaras, 2008, p. 165). Judging by this information, almost all researchers, mainly Akdes Nimet Kurat, agree that he was a Turkish bey who participated in the conquest of Anatolia before he was taken prisoner (Kurat, 1987, p. 41; Turan, 1973, p. 88). The fact that Anna Komnena declared that "he crossed all of Asia (Anatolia), fighting before being taken prisoner", also proves this finding (Komnena, 1996, p.183). In Danismend-name, which is an important source about the conquest of Anatolia by the Turks, Chavuldur Chaka Bey (in Turkish Çavuldur Çaka $B e y)$ is mentioned among the beys $(G a z i-A k \imath n c l)$ who raided the area from Central Anatolia to Constantinople (Sümer, 1999, p. 321; Ayönü, 2002, p. 600; Turan, 1984, p. 54), while Turkish historians Mükrimin Halil Yınanç (Yınanç, 1934, p. 127) and Akdes Nimet Kurat (Kurat, 1987, p. 41) mention that Chaka Bey who belonged to the Oguz Çavuldur clan and the Turkish bey captured by the Byzantines may be the same person, while the Turkish historian Osman Turan admits that these two characters refer to the with more certainty (Turan, 1984, p. 88).

\section{Renowned prisoner in the Byzantine palace}

Chaka Bey, who joined the invaders to the Byzantine lands in Anatolia by order of the Seljuk Sultan Alp Arslan after the battle of Malazgirt, enters the historical theater during the struggle for the Byzantine throne. Sources associate the name of Chaka Bey with Nikephoros III Botaneiates, the Byzantine emperor (1078-1081), who entered the throne with the help of Seljuk Turks in 1078 (Turan, 1984, p. 54; Ayönü, 2009, p. 3). According to the information provided by Anna Komnena, during a raid on Byzantium, Chaka Bey was captured by the Byzantine commander Alexandros Kabalikos because of his lack of experience and young age. Kabalikos presented Chaka Bey to Emperor Nikephoros Botaniates, who sensed the talent of the Turkish teenager and took him to his palace (Turan, 1984, p. 87). Given that Botaneiates reigned from 1078 to 1081, we can say that Chaka Bey's captivity in the Byzantine palace took place in those years. It is known that Emperor Botaneiates held Chaka Bey in high esteem and awarded him the title of a protonobilissimos, ${ }^{4}$ and, in response, Chaka

4 This title, meaning the first of the noblest, also involved receiving a large income (Komnena, 1996, p. 233; Zonoras, 2008, p. 165; Angold, 1995, p. 160). 
Bey promised allegiance to the Emperor (Komnena, 1996, p. 233; Ostrogorsky, 1981, p. 340). While in the Byzantine palace, Chaka Bey studied Greek and Latin, and he learned about the military and political structure of Byzantium (Komnena, 1996, p. 232; Turan, 1984, p. 88). We also see that from a conversation between Chaka Bey and Constantine Dalassenos in Anna Komnene's account. Chaka Bey spoke in Greek with Constantine Dalassenos and even turned to that nobleman by his first name (Komnena, 1996, p. 232). It is clear from this conversation that Chaka Bey belonged to a noble family, and had a high status in the Byzantine palace.

\section{Chaka's arrival to Smyrna}

The exact date when Chaka Bey left Constantinople is unknown, however, by examining the string of events described in the sources, it seems that this event took place in 1081. However, why did Chaka Bey, despite his high status and the many privileges granted by Nikephoros Botaniates, leave Constantinople instead of remaining in Byzantine service? There were many Seljuk Turks who were captured in the wars or took refuge in Byzantium due to a conflict with the Seljuk government, who managed to raise to the highest offices in the Byzantine court and have many powers there (Merçil, 1994, p.709; Kafesoğlu, 1958, p. 129). We can find an answer to this question in Anna Komnene's book, that provides detailed information about the life and activities of Chaka Bey. According to the author, Chaka fled Constantinople since the great status and privileges granted to him by Emperor Nikephoros Botaneiates were taken away by Alexios I Komnenos (1081-1118), who entered on the Byzantine throne in 1081 (Komnena, 1996, p. 233; Zonaras, 2008, p. 157; Kurat, 1987, p. 24).

However, there is another question. Why did Chaka Bey, who was previously a Seljuk subject, prefer to establish an independent principality (in Turkish beylik) in Smyrna, instead of joining Suleiman Shah, who had conquered Nikaia during this period? Without a doubt, it was related to his personal ambitions. Finally, why Smyrna? Of course, Chaka Bey, who was known among his countrymen in Anatolia, could not press on the Balkans where Pechenegs were intensely present. In the north-western part of Anatolia there were the Seljuks who dominated the whole region of Bithynia. However, although in Smyrna and around it there was a dense Turkish population, there was no one who could compete with him except Tanrıbermiş Bey ${ }^{5}$ in Ephesus. More importantly, Chaka Bey, who was able

5 The principality of Tanrıbermiş (Tannvermiş Beyliği): This Turkish principality ruled in the region of Ephesus in western Anatolia during the years 1074-1098. One of the Turkmen rulers, 
to maintain greater contact with the sea during his stay in Byzantium, must have noticed that the Turks lacked a war fleet.

In those years the Byzantine Empire was pressed by the Pechenegs in the Balkans and the Seljuks in Anatolia. It was well-established and strong only in the seas. Gaining an advantage on the seas with a powerful fleet to be created could mean the end of Byzantium. Smyrna was also the most suitable place to build a powerful navy. Chaka Bey took into account all these factors, also using the fact that Byzantium was occupied by the Pechenegs in the Balkans. He set off to Smyrna and captured it (Ayönü, 2009, p. 4).

Knowing that he first needed to first dominate the sea, Chaka Bey built a fleet of war as his first task in Smyrna. Anna Komnene's account states that a local Byzantine ship master was hired build the fleet (Komnena, 1996, p. 229). However, one cannot identify the name of the master of Smyrna, about whom Anna said that he was building ships for Chaka Bey. The warships built by Chaka Bey consisted of galleys which were covered and were called dromons (Figure 4). Qualified sailors in the fleet consisted of local Byzantines masters and Turkish warriors. Available information about the first Turkish navy created by Chaka Bey in Western Anatolia is very general. Unfortunately there are no more details on how and when they built a fleet of war. Turkish historian Halil N. Hatipoğlu, who conducted one of the most recent studies of naval history, noted that Chaka Bey built this fleet in a shipyard in Ephesus in 1081 and that it consisted of forty ships (Hatipoğlu, 2005, p. 87). Anna Komnena, our only source on this subject, writes that Chaka Bey started the raids "when he had many galleys [Çektiri in Turkish] and forty privateers" (Komnena, 1996, p. 230).

\section{Ensuring Turkish domination in Smyrna and the surrounding islands}

When Chaka Bey took action, completing the necessary preparations to fight, the Byzantine Empire was still occupied with the Balkans. Klazomenai (in Turkish: Urla) was the first place conquered by Chaka Bey who wanted to take advantage of the current situation in Byzantium. Then, heading Phokaia (Turkish: Foca), Chaka Bey conquered it without trouble. From there he went on Lesbos (Turkish: Midilli). When Chaka Bey

who came to Anatolia after the Battle of Malazgirt, Tanrıbermis Bey played an important role in the conquest of Anatolia, taking the region of Ephesus. He declared his state of Ephesus in the year 1074. However, during the First Crusade in 1098, Tanrıbermiş Principality was destroyed by the Crusaders and the Byzantine troops under the command of Alexander I Komnenos. 
demanded of Alapos, who governed the island, to surrender, he realized that he could not defend it and fled to Constantinople. In this way, Lesbos surrendered without bloodshed (Komnena, 1996, p. 268; Kurat, 1987, p. 46). After the conquest of Lesbos, Chaka Bey led his troops also to the island of Chios (Sakız Adası in Turkish) and subdued that island too. He probably needed to add these two islands to his estate, letting troops on the island of Samos (Sisam in Turkish) and Rhodes in the next year (Zonaras, 2008, p. 165; Kurat, 1987, p. 46; Geyiklioğlu, 2003, p. 255)

When the message that the eastern Aegean islands had been conquered by Chaka Bey reached Constantinople, the Byzantine Emperor Alexios I Komnenos was forced to take action against him and sent a fleet under the command of Niketas Kastamoniates. It seems that now it is not possible to estimate the number of the Byzantine ships and tell what kind of vessels there were, and how numerous were the crews. Anna Komnena claims that Niketas Kastamoniates was sent in, and that he was defeated in the confrontation with Chaka Bey, and many of the ships that he had brought along fell into the hands of Chaka Bey (Komnena, 1996, p. 230; Alptekin, 1987, p. 478).

This first naval battle that the Turkish fleet won in Aegean waters is called the Battle of the Oinousses Islands (in Turkish, Koyun Adalar Savaşı), and it took place between the island of Chios and Çeşme-Smyrna. (Figure 3) Historian H. Hatipoğlu estimated Chaka Bey's forces in this battle as a fleet of 50, including 17 dromons (Çektiri in Turkish) and 33 sailing ships (Hatipoğlu, 2005, p. 89). It is clear that the clash resulted in the advantage of the Turkish forces. However, we do not have any details about the course of the battle, and the tactics and strategies used. On the other hand, Halil N. Hatipoğlu specifies the date of the battle on May 19, 1090. According to Zonoras, after this battle Chaka Bey organized new raids, on the islands of Samos and Rhodes, and conquered the region again (Zonoras, p. 737).

After the defeat of the Byzantine forces at the Battle of the Shep Islands, Byzantine emperor Alexios sent a second fleet under the command of Constantine Dalassenos. Dalassenos was aided by a commander named Opus, but they were accompanied by 500 knights from Flanders. It is very likely that among the Byzantine troops there were also Pecheneg and Uz mercenaries. Dalassenos ventured straight to Chios, besieging the fortified villages that were in the hands of the Turks on the island. When Chaka Bey learned about this situation, he took action from both land and sea to invade the island of Chios. In response to Chaka Bey's progress, a deputy was sent to fight a battle against him wherever he was (Komnena, 1996, p. 231).

During this time, Chaka Bey, who attacked from the sea in parallel with his own forces advancing from the mainland, encountered in the 
Byzantine ships the vicinity of Chios. Byzantine army under the leadership of Opus fled, not daring to challenge the forces of Chaka Bey. According to Anna Komnene, during this operation, Chaka Bey tied the ships together with chains in order not to disturb the combat formation and prevent possible escapes, thus squeezing the Byzantine ships in the harbor of Chios and went ashore for an offensive against the Chios fortress (Komnena, 1996, p. 231). Constantine Dalassenos, who saw that the situation became dangerous for him after the defeat of the Flemish knights who tried to resist, escaped from the castle and took refuge in Bolissos, a small fortified area on the island of Chios. If the information given by Anna Komnene is correct, during these struggles, Chaka Bey collaborated with the Pechenegs and Uzes serving the Byzantines and learned about the plans of the Byzantines (Komnena, 1996, p. 231).

According to Anna Komnene, Dalassenos met with Chaka Bey, trying to fix its position on the fortified site. During this conversation, as Anna refers, providing invaluable information about her biography quoting Chaka Bey. According to Anna, Chaka Bey secretly left the island of Chios after this meeting, in order to bring along a large force, and Constantine Dalassenos took over the castle of Chios proceeded to the island of Lesbos from there (Komnena, 1996, p. 234). Following clashes with the forces of Constantine Dalassenos, Chaka Bey built new ships in the shipyards of Ephesus and Smyrna, forming a larger fleet. Hatipoğlu determined that this newly-built fleet consisted of dromon assault ships, on top of two- and three-row rowing boats (Hatipoğlu, 2005, p. 89).

Chaka Bey strengthened his fleet. His aim was to subdue the coastal areas extending from the Dardanelles (Hellespont) to Smyrna and Peninsula of Gallipoli to Thrace (Illgürel, 1993, p. 187; Gencer, 2005, p. 344). In order to achieve this, he contacted the Pechenegs, who drove the Byzantines from the Balkans (Komnena, 1996, p. 247). At this time, the Byzantine fleet was sent to the Dalmatian coast. Taking advantage of the opportunity, Chaka Bey again captured the islands of Chios, Samos and Rhodes (1090). As a consequence of these events, Byzantium concluded a treaty with the Cumans, the Pechenegs' enemies. The Pechenegs, who had approached Adrianapole (Edirne in Turkish) in order to attack the Byzantine Empire, were destroyed by Cuman and Byzantine forces (the battle of Lebunium: April 29, 1091) (Komnena, 1996, p. 255; Angold, 1997, p. 133; Ostrogorski, 1981, p. 333; Kurat, 1937, p. 197). Chaka Bey, who was not able to prepare his army and fleet, did not make in time to aid them. Chaka Bey, who was left without allies, wanted to cooperate with Kilidj Arslan, who was moved to the Anatolian Seljuk throne. After the destruction of the Pechenegs, Alexios sent his army and navy to strike Chaka Bey (1092). Byzantine forces besieged Lesbos for three months. Finally, Chaka Bey agreed 
to leave Lesbos provided he could safely withdraw his soldiers and sailors from the island. However, when they boarded the ships, Byzantine commanders suddenly attacked Chaka Bey and his soldiers, intercepting some of the Turkish ships and burning some of them. Chaka Bey managed to escape and get to Smyrna. Byzantine forces also captured the island of Samos (Komnena, 1996, p. 267).

\section{Chaka Bey's death and the disappearance of the first Turkish seaside principality}

Chaka Bey soon prepared a new fleet of two- and three-row offensive dromons. He re-established his dominance on Lesbos, Chios, Samos and Rhodes. He extended his conquests in the Dardanelles (Hellespont). In 1092, Chaka Bey allied with the Sultan of the Seljuk Turks, Kilidj Arslan, who at that time had the largest military power in Anatolia. To strengthen this alliance and friendship, Chaka Bey also established a family bond with Kilidj, giving his daughter to the Seljuk Sultan (Turan, p. 93). Chaka Bey planned to reach the Marmara Sea, by conquering the northern coast of the Aegean and the Dardanelles (Turkish: Çanakkale) in Anatolia, to conquer Constantinople from there. His attempts to press towards the Marmara Sea after acquiring the Dardanelles worried the Byzantine Emperor and prompted him to seek ways to remove this threat that had fallen on the Empire. Alexios used diplomacy as a weapon and forced Chaka Bey to confront Kilidj Arslan (Komnena, 1996, p. 269; Kurat, 1987, p. 74; Kafesoğlu, 1953, p. 112). To get out of this situation, the Emperor wrote to Kilidj Arslan and provoked him against Chaka Bey.

Glorious Great Sultan Arslan Kilidj!

As you know that the Sultanate passed to you as an inheritance from your father. However, your father-armed Chaka is apparently armed against the Greek state and is forcing Greek citizens to call him "Basil," but of course, this is a scam. In fact, this man, with such a great deal of experience and great competence, knows that he has no right to basil over the Greeks and that it is impossible [for him-transl.] to lead such a large country. The whole game, which Chaka Bey had built, is directed against you. In the face of this situation, you should not leave him unattended and be discouraged; all you have to do is not fall asleep in order not to become deprived of power. As far as I am concerned, with God's help, I expel him out of the borders of the Greek state; I invite you to protect your country and your sovereignty in your best interest, and if possible, by peaceful means, if he 
does not want it, take him back under you domination by force (Komnena, 1996, p. 370).

In addition to these suggestions from Alexios, Kilij Arslan was also not satisfied with the activity of Chaka Bey on his side of the Dardanelles, since he considered this territory as lying in his direction of conquest. The Byzantine Emperor Alexios turned the situation to his advantage, having persuaded Kilij Arslan to take action against Chaka Bey (Demirkent, 1996, p. 17). Chaka learned that Seljuk armies took action against him when he was keeping Aydos (Abydos) under siege, which was a Byzantine customs gate with Edremit. The conflict with the Seljuks, of the greatest power of the era certainly was not in Chaka Bey's interest. Therefore, he was looking for ways to remedy the situation by negotiating with Kilij Arslan. Anna Komnene describes the encounter between Chaka Bey and Kilij Arslan, and Chaka Bey's assassination:

Chaka saw that he was threatened by enemies on land and sea. The ships he was building were not yet finished, and his army was also not enough to fight against both the Greek and Sultan's armies; he was desperate and wanted to meet the Sultan because he did not know about the intrigue the Emperor had prepared. The Sultan first greeted him in a friendly way and prepared a feast in his honor. At the time when the beverage worked, the Sultan drew his sword and knocked Chaka dead on the ground (Komnena, 1996, p. 371).

Had Chaka Bey not been assassinated by his son-in-law Kilij Arslan, and had Kilij Arslan formed an alliance with him instead of killing him, Byzantium could have been conquered by these two commanders, and the fate of the Seljuk state would have been completely different. In addition, should Chaka Bey have lived during the Crusades, the Crusaders would have never entered Anatolia so smoothly. Indeed, after the death of Chaka Bey, the armies of the Crusaders passed from the Strait of Istanbul to Anatolia and captured the city of Nice, the capital of the Seljuks, in the year 1097. Kilij Arslan, who could not stop the Crusaders was forced to leave the Aegean region, along the coast of the Marmara Sea and retreat to central Anatolia. Emperor Alexios, in order to take advantage of this, sent an army and fleet to Smyrna and the islands of the Aegean Sea. The Byzantines slain ten thousand people in the surrendering Smyrna (Komnena, 1996, p. 338; Ayönü, 2009, p. 5). Thus, the 17-year Turkish dominance in Smyrna ended in a very tragic way. 


\section{Conclusion}

The assassination of Chaka Bey had negative consequences from the point of view of Turkish history. First of all, after the death of Chaka Bey, who placed the sea and the navy at the center of his military and political strategy, the passage of the Crusaders from Anatolia and the exit of coastal regions from Turkish domination with Smyrna delayed the development of the navy among Turks in Anatolia. It is worth noting that the experience gained by the Turks as a result of the naval activities initiated by Chaka Bey in the last quarter of the $11^{\text {th }}$ century is an important factor that enabled the Turks to become an important superpower in the Mediterranean and the Black Sea.

Chaka Bey was an important Turkish Bey, who got to know the Byzantine state structure very well during the years of his captivity and managed his operations accordingly. The fact that he was aiming directly at the Byzantine throne, the idea of besieging Constantinople and even creating alliances with Turks in distant areas testify to his individuality and superiority to all other Anatolian Turkish beys. The captivity did not destroy Chaka Bey, but further strengthened him. This Turkish admiral, who was a serious threat to the Byzantine state, was not able to maintain his existence in the face of the Byzantine policy to come through the centuries. First, he lost his confidence in the Pechenegs, who were his allies, then and he lost the trust and support of Kilij Arslan and paid the price of his life. Not much is known about Chaka Bey, who took control of the Aegean Sea for a significant period in the last quarter of the $11^{\text {th }}$ century. We hope that new research on Chaka Bey and his principality will be carried out and new sources will be made available and studied in every aspect of the Turkish admiral's life. We believe that the role which he and his principality played in the history of Turkey and the world, was very important.

\section{REFERENCES}

Alkayıs, M.F. (2014). Eski Türkçede Deniz ve Denizcilik Kavramları. In Uluslararast Piri Reis ve Türk Denizcilik Tarihi Sempozyumu Türk Denizcilik Tarihi Bildiriler (pp. 13-26). Ankara: Türk Tarih Kurumu.

Alptekin, C. (1987). İzmir Türk Beyliği (Çaka Beyliği). In Tarihte Türk Devletleri (C. II, pp. 476-480). Ankara: C.II.

Angold, M. (1995). Church and Society in Byzantium Under the Comneni, 1081-1261. New York: Cambridge University Press.

Angold, M. (1997). The Byzantine Empire, 1025-1204. A Political History. London \& New York: Longman. 
Ayönü, Y. (2009). İzmir'de Türk Hakimiyeti’nin Başlaması. Türk Dünyası Incelemeleri Dergisi, cilt IX, sayı 1, 1-8.

Boşol, R.Ö. (2014). Akdeniz Çalışma Kültürü, Kırklareli Üniversitesi İktisadi ve İdari Bilimler Fakültesi Dergisi, Kırklareli: cilt 3, sayı 1, 40.

Cahen, C. (1994). Osmanlilardan Önce Anadolu'da Türkler (Y. Moran, Trans.). İstanbul.

Daş, M. (2009). Türklerin Bizans ve Venedik’le Denizlerdeki İlişki ve Mücadeleleri (XI-XIV. Yüzyıllar). In İ. Bostan i S. Özbaran (Eds.), Türk Denizcilik Tarihi (pp. 49-59). İstanbul: Deniz Kuvvetleri Komutanlığı Yayınları.

Demirkent, I. (1996). Türkiye Selçuklu Sultanı I. Kılıç Arslan. Ankara: Türk Tarih Kurumu.

Demirkent, I. (2005). Bizans Tarihi Yazıları. İstanbul: Dünya Kitapları.

Gencer, A.İ. (2005). Doğu-Batı Çatışması Ekseninde Anadolu Türk Denizciliğinin Başlaması. İstanbul: Semavi Eyiceye Saygı. Tarihte DoğuBatı Çatışması.

Geyiklioğlu, H. (2003). Selçuklular'ın Deniz Politikası ve Denizcilik Faaliyetleri. Atatürk Üniversitesi Türkiyat Araştırmalarn Enstitüsü Dergisi, Say1: 22, 255-256.

Hatipoğlu, M.N. (2005). Orta Çă̆da Akdeniz'de Deniz Güçlerinin Incelenmesi, Anadolu'da İlk Türk Denizciliği (Umur Bey'in Epir Harekâtı). İstanbul: Deniz Kuvvetleri Komutanlığı, Deniz Basımevi.

İlgürel, M. (1993). Çaka Bey. In İslam Ansiklopedisi, vol. 8 (pp. 186-188). İstanbul: Türkiye Diyanet Vakfi.

Kafesoğlu, İ. (1953). Sultan Melikşah Devrinde Büyük Seşçklu Imparatorluğu. İstanbul.

Kafesoğlu, İ. (1984). Selçuklu Çağındaki İzmir Türk Beyi’nin Adı: Çaka mı, Çă̆a mı, Çakan mı? Edebiyat Fakültesi Tarih Dergisi, 34, 55-60.

Koca, S. (1997). Sultan I. Izzeddin Keykavus (1211-1220). Ankara: Türk Tarih Kurumu Yayınları.

Komnena, A. (1996). Alexiade, Anadolu'da ve Balkan Yarmadasi'nda İmparator Aleksios Komnenos Dönemi'nin Tarihi, Malazgirt'in Sonrast (B. Umar, Trans.). İstanbul.

Kurat, A.N. (1937). Peçenek Tarihi. İstanbul: Devlet Basımevi.

Kurat, A.N. (1966). Çaka Bey, İmir ve Civarnda Adalarn Ilk Türk Beyi. Ankara.

Merçil, E. (1994). Bizans'ta Selçuklu Hanedan Mensupları. XI. Türk Tarih Kongresi Bildiriler (II, pp. 709-710). Ankara.

Ostrogorsky, G. (1981). Bizans Devleti Tarihi (Fikret Işıltan, Trans.). Ankara: Türk Tarih Kurumu.

Sevim, A. \& Merçil, E. (1995). Selçuklu Devletleri Tarihi. Ankara.

Turan, O. (1973). Türkler Anadolu'da. İstanbul: Hareket Yayınları.

Turan, O. (1984). Selçklular Zamanında Türkiye. İstanbul. 
Yınanç, M.H. (1934). Türkiye Tarihi, Selçuklu Devri I: Anadolu'nun Fethi. İstanbul.

Zonaras, I. (2008). Tarihlerin Özeti. Transl. Bilge Umar. İstanbul: Arkeoloji ve Sanat Yayınları.

Sabire Arık - Assistant Professor at the Department of Linguistic and Historical Geography of the Ankara University. His research interests include Polish history, literature and culture. Most recent publication: "Leh Rahip Ignacy Hołowiński’nin Seyahatnamesinde İzmir ve Çevresi”. Ankara Üniversitesi Dil ve Tarih-Coğrafya Fakültesi Dergisi 2020, cilt 60, sayı 1: 195-211. 


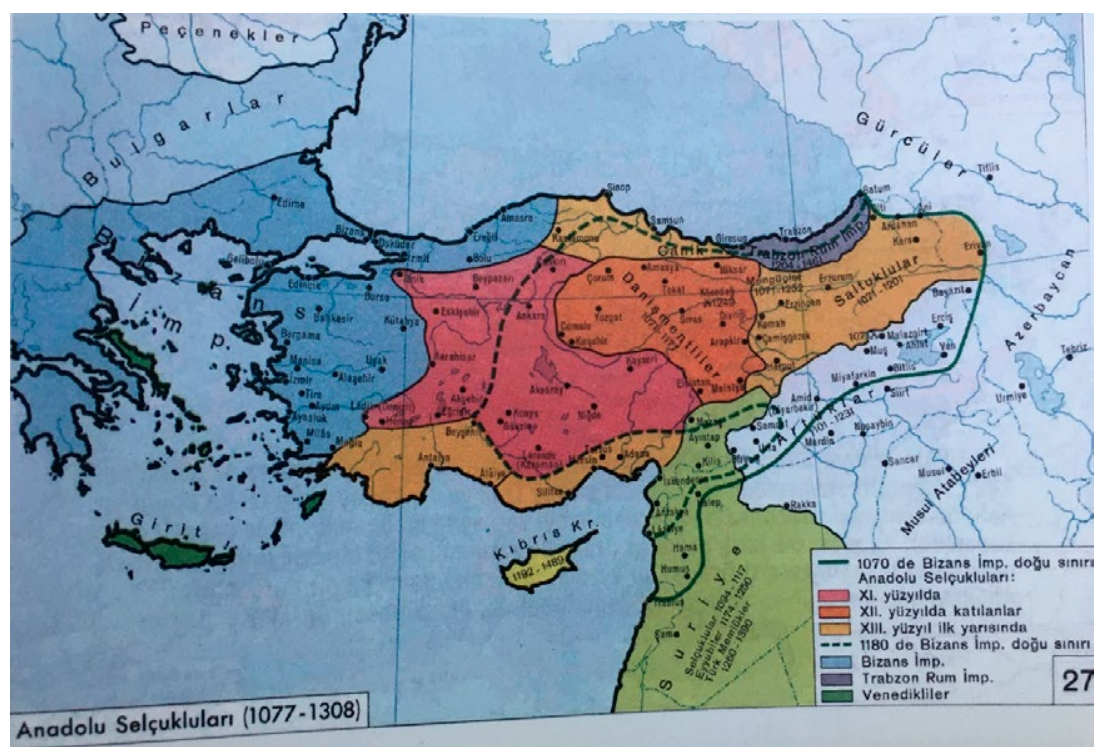

Figure 1. The Anatolian Seljuks; Hatipoğlu, 2005, p. 88.

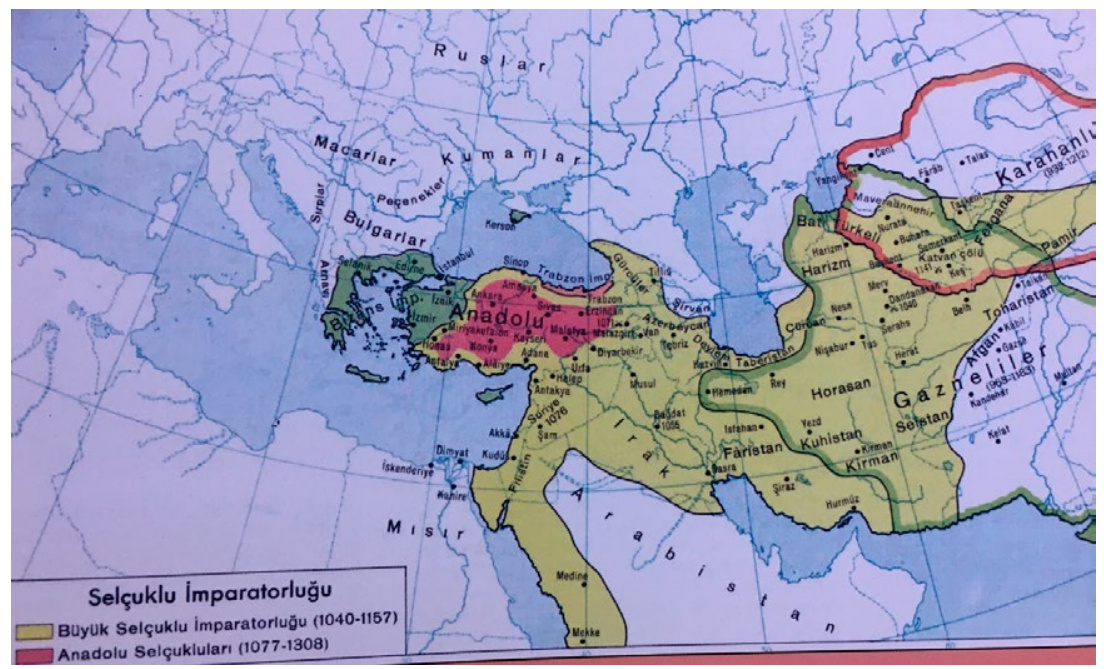

Figure 2. Map of the Great Seljuk State; Hatipoğlu, 2005, p. 90. 


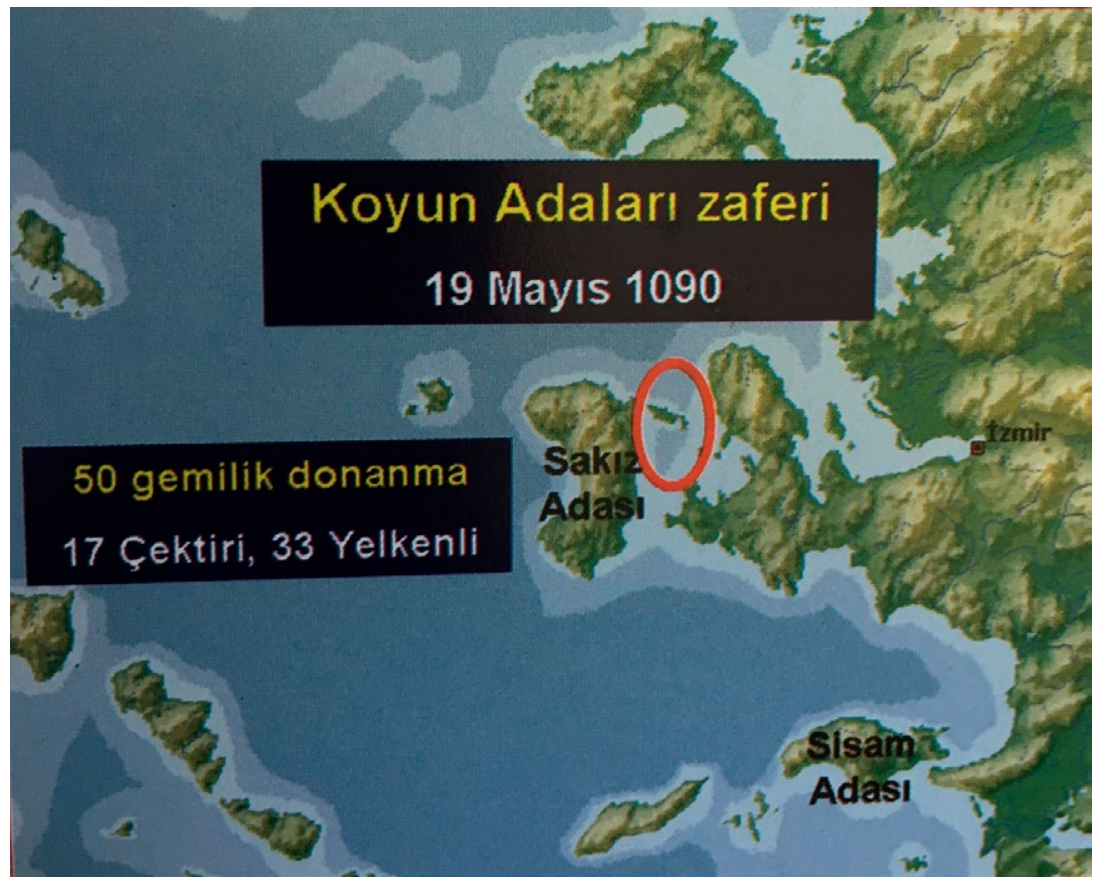

Figure 3. The Oinousses Islands; Hatipoğlu, 2005, p. 89.

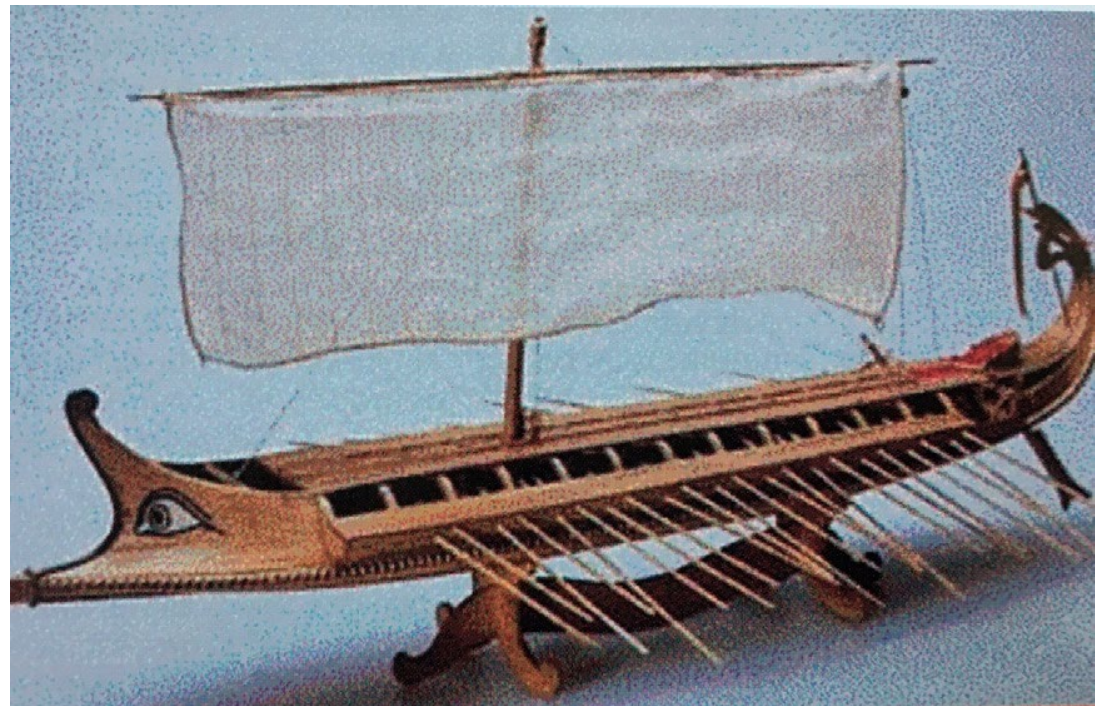

Figure 4. A dromon; Hatipoğlu, 2005, p. 17. 